\title{
Motivation Levels of Aviation Students in Education: An Application to Measure the Level of Motivation
}

\author{
Harun Yılmaz ${ }^{1}$, Savaş S. Ateş ${ }^{2 *}$ \\ ${ }^{1}$ İskenderun Technical University, Faculty of Aeronautics and Astronautics, Aviation Management Department, Hatay, Turkey (ORCID: 0000-0002-8467-9019), \\ harun.yilmaz@iste.edu.tr \\ 2 * Eskişehir Technical University, Faculty of Aeronautics and Astronautics, Aviation Management Department, Eskişehir, Turkey (ORCID: 0000-0003-2462-0039), \\ ssates@eskisehir.edu.tr
}

(İlk Geliş Tarihi 6 Ekim 2021 ve Kabul Tarihi 29 Aralık 2021)

(DOI: $10.31590 /$ ejosat.1005457)

ATIF/REFERENCE: Yılmaz, H. \&.Ateş, S.S. (2022). Motivation Levels of Aviation Students in Education: An Application to Measure the Level of Motivation, European Journal of Science and Technology, (33), 297-305.

\begin{abstract}
Motivation is a situation created by external and internal factors that activate the person who comes across at every moment of life to do a job. As in every field, it is essential to have various sources of motivation that lead to the goal for the continuity of the success of the people in education. From time to time, it is seen that the level of motivation decreases due to some reasons. There is a need for steps such as focusing, imagining, taking a break from work, etc. that will motivate some people again or increase the level of motivation. It should not be forgotten that while doing all these, it should not be separated from the predetermined purpose. It is a known fact that the motivation levels of those who can be constantly positive towards life are high. Most of the time, it is necessary to get help and support from people who will provide motivation. That's why we should always have people with whom we can agree and who value us. The study aims to measure the motivation levels of students studying in aviation departments at higher education level in Turkey. In the literature part of the study, the concepts of motivation and education are discussed. Moreover the importance of motivation in terms of education is explained. In the findings and evaluations section, a questionnaire was applied to measure the motivation levels of the students studying in the Aviation Departments. Evaluations were made by analyzing the applied survey data.
\end{abstract}

Keywords: Management and Organization, Motivation, Motivation in Education, Aviation, Aviation Education.

\section{Havacılık Öğrencilerinin Eğitimde Motivasyon Düzeylerinin Ölçülmesine Yönelik Bir Araştırma}

$\ddot{0} \mathbf{z}$

Motivasyon hayatın her anında karşımıza çıkan kişiyi, bir işi yapmak için harekete geçiren dışsal ve içsel etkenlerin oluşturduğu bir durumdur. Her alanda olduğu gibi eğitimde de kişilerin başarısının devamlılı̆̆ için hedefe götüren çeşitli motivasyonlar olması gerekmektedir. Azalan motivasyon düzeyine karşı odaklanma, hayal etme, yapılan işe ara verme vb bir takım kişiyi tekrar motive edecek veya motivasyon düzeyini yükseltecek adımlara ihtiyaç duyulmaktadır. Bütün bunları yaparken önceden belirlenen amaçtan ayrılmaması gerektiği unutulmamalıdır. Hayata karşı sürekli pozitif olabilenlerin motivasyon düzeylerinin yüksek olduğu bilinen bir gerçektir. Çoğu zaman motive olmayı sağlayacak kişiler ile görüşerek onlardan yardım ve destek alınmalıdır. Bu yüzden çevremizde her zaman anlaşabildiğimiz, bize değer veren kişiler ile hayatımızda paylaşımlar gerçekleştirilmelidir. Çalışma, Türkiye'de yüksek öğretim düzeyinde havacılık alanında öğrenim gören öğrencilerin eğitimde motivasyon düzeylerinin ölçülmesi amacını taşımaktadır. Emniyet ve güvenlik konularında hata ve hileye yer verilmeyen havacılık sektöründe görev yapacak kişilerin motivasyon düzeylerinin yüksek olması performanslarına bağlı olabilmektedir. Havacılık sektöründe ihtiyaç duyulan kalifiye elemanların yetiştirildiği eğitim kurumlarında öğrencilere motivasyonun önemi anlatılmaya çalışılmıştır. Çalışmanın literatür bölümünde motivasyon ve eğitimde motivasyon kavramları ele alınmış olup motivasyonun eğitim açısından önemi anlatılmıştır. Bulgu ve değerlendirmeler bölümünde ise Havacılık Bölümlerinde öğrenim gören öğrencilerin motivasyon düzeylerini ölçmeye yönelik uygulanan anket verileri analiz edilerek değerlendirmeler yapılmıştır.

Anahtar Kelimeler: Yönetim Organizasyon, Motivasyon, Eğitimde Motivasyon, Havacılık, Havacılık Eğitimi.

* Corresponding Author: ssates@eskisehir.edu.tr 


\section{Introduction}

New technological developments and rapid change have accelerated the process of societies becoming an information society. The way to reach the level of information society is through education. Education is a process that begins in the womb of a person before he is born and continues until the end of his life. However, the face-to-face or distance education process, which takes place in a physical environment, covers one-third of human life. In this educational process, the individual's approach to education and the level of motivation are the most important factors in success. The high or low level of motivation of the individual in the education process also significantly affects the perception power of the individual.

While the average rate of young population in the world (2019) is $16 \%$, this rate is $15.6 \%$ in Turkey. There are more than 7 million 940 thousand university students and over 11 million primary and high school students in Turkey [18]. Generation Z has come to a world with the internet. Since their access to information is easy and fast, they get bored quickly and prefer an unconventional life. Motivation is a factor that affects an individual's productivity by enabling individuals to use their knowledge and conceptual and technical skills. It is useful for individuals with intrinsic motivation to use their energy, thoughts and ideas for educational purposes in terms of explaining problems and finding innovative solutions.

Instead of accepting the information conveyed to him, the individual should actively participate in the process of making sense by interpreting, questioning and researching the information. Using the knowledge learned theoretically in practice will make it permanent. With today's technologies, students' application of theoretical knowledge in simulation also increases the quality of education. In addition, new teaching methods that will increase the quality of education try to ensure that students participate in classes in an interactive environment as much as possible.

Motivation means the power that moves the organism for any purpose [19] and is defined as the process of consistency, goal and perseverance that a person has shown to reach a goal [16].

If there is no consistency and compatibility between the expectations of the students and the results of their efforts to meet these expectations, a lack of motivation can be experienced. For this reason, students need to be internally and externally motivated to maintain their concentration and effort. Instructional designers recommend the careful use of external reinforcers to maintain and develop students' intrinsic motivation for the lesson [9]. In this study, the concept of motivation and the results of studies on motivation are discussed theoretically. Research data were collected by choosing an appropriate scale and the data were analyzed with SPSS.

\section{Material and Method}

\subsection{Motivation Concept}

Motivation is a situation that directs human behaviors in every moment of life and causes them to exhibit certain behaviors in order to meet their needs. It is one of the most important factors in achieving success, especially in working life. Motivation is the power that comes from within the person e-ISSN: 2148-2683 and the desire to do a job. Motivation, which can be defined as an energy that directs and determines human behavior, covers the forces related to people's thoughts, hopes, beliefs, in short, desires, needs and fears [19].

It is the vital goal of both individuals and organizations and the continuation of life. There are basic psycho-social needs for the continuation of life. While the target of persons is to meet their needs, the target of organizations is to provide profitability for the continuation of their activities [20]. Motivation is a concept related to how employees are treated and how individuals feel about the work they do. Motivation is vital when it comes to productive work [13].

Needs and wishes, which are the basis of the concept of motivation, are shaped by the culture, social structure, and emotional and spiritual state of the individual. Therefore, it can be said that the level of motivation of the individual is closely related to all the objects with which he/she is related [20]. Motivation not only differs between people, it can also differ for the same person at different times [16].

As long as people are satisfied with their work and work environment, they work more efficiently. It can be said that economic satisfaction while working is a necessary but not a sufficient condition. When the historical development of the management process is examined, the ways of motivating people to work have been investigated. The term motivation was first used in the writings of psychologists in England and the USA in the 1880s. The 1950s was a very rich period in terms of the development of motivation theories, and the developed theories were criticized and their validity was discussed [16].

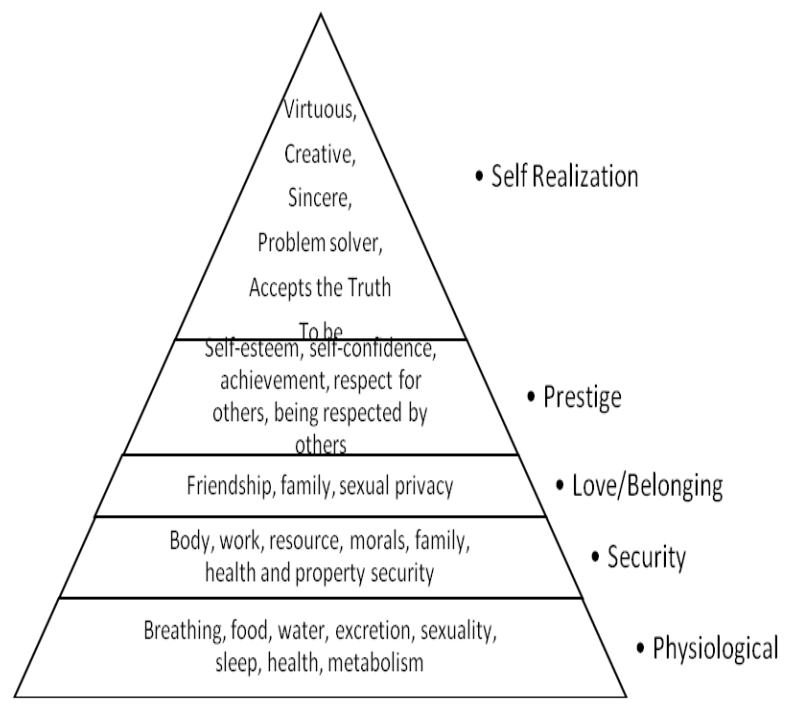

Figure 1. Maslow's Pyramid of Needs (Maslow, 1943) [6].

In Abraham Maslow's hierarchy of needs, which is among the motivation theories shown in Figure 1, it is assumed that every person has five basic needs in a hierarchical order [16].

- Physiological: Hunger, Thirst, protection, sexuality and other bodily needs.

- Safety: Protection from physiological and emotional harm.

- Social: Relationship, attachment, acceptance, friendship. 
- Dignity: Internal factors such as self-esteem, autonomy, achievement, and external factors such as status, recognition, attention.

- Self-Realization: The motivation to use talents for an innovative purpose, to develop, to use the potential, to benefit from their talents.

Tests on Maslow's $(1943,1954)$ hierarchy of needs confirm that people around the world will be motivated by essentially the same basic needs [8]. In 20th century age, especially in advanced industrial societies, giving weight to automation, sharing a job between human and machine and producing a large number of the same kind of product at a time with mass production reduces the satisfaction of the worker from his job. Workers working in such environments are not satisfied enough because they can only see a small part of a job, not the whole. Workers, whose ties with their superiors have weakened as a result of the vertical hierarchy that emerged with the increase in management levels, cannot maintain close contact. By identifying the factors that will motivate their employees, managers should create an environment where they both meet their personal needs and work to achieve the goals of the organization [14]. Material and moral motivation tools that can motivate employees to achieve these goals can be listed as follows: [19]:

- Wages, bonuses and awards,

- Social amenities,

- Appreciation, praise and constructive criticism

- Promotion and career development opportunities

- To provide social status,

- To improve the working environment and working conditions,

- Work safety,

- To provide working order,

- moralizing,

- To provide prestige

- Giving importance to social activities

- Giving interesting and important work,

- Authorize,

- Giving initiative and responsibility

- Giving importance and value,

- To implement an open management policy,

- Educating and raising

At the cross-cultural level, managers should understand that different people can be motivated through different sets of motivators and are shaped by the external and internal culture in which people grow up [8]. As a result, it is accepted that the performance and productivity of the individual with a high level of motivation will increase.

\subsubsection{Motivation In Education}

All of the activities aiming at positive changes in the knowledge, skills and behaviors of the individual within a certain period of time are defined as education [15]. Kullmann \& Seidel stated that in the teaching activity, motivation provides the necessary power and energy at the beginning stage and that the unmotivated learning process cannot reach the expected goal. Moreover, there is a cyclical relationship between motivation and learning performance [4]. Schumann explains the cycle between a strong motivation and the learning process as follows:

e-ISSN: 2148-2683
"Positive emotions (motivation) positively affect the cognitive process; cognitive process leads to new knowledge; learned new knowledge also strengthens positive emotions (motivation)" [10].

Although the effectiveness of motivation on learning and behavior is known and accepted, it is not known how and what it means in an instructional design. The reason for this situation is that motivation is a factor that cannot be seen directly and therefore cannot be measured. Because motivation is a process, not a result. Since it is a process, it cannot be observed directly. Inferences about the motivation process can only be made by observing which activities individuals prefer, how much effort they put into these activities, how persistent they are in continuing these activities, or by observing the verbal statements of individuals [5].

There is a direct correlation between motivation and performance. The higher the motivation, the higher the performance. However, environmental factors should be at a sufficient level along with the knowledge, skills, education and other abilities of the person [4]. The complex structure that distinguishes educational institutions from other organizations necessitates a wide variety of motivational tools to be applied. According to the general opinion, the low motivation level of the instructors causes the student's motivation level to be low [11]. Researchers emphasize the necessity of measuring the motivation levels of students who can show different motivational characteristics [9]. The active learning process is necessary for teachers as well as for students. It has been observed that students' motivation levels increase thanks to active learning and their classroom discipline problems decrease as they become active [9]. Educational subjects should be more compatible with students' motivation levels and learning methods. The common goal of educators is to help increase the learning level of students, regardless of ability level. Studies have shown that students are more willing to learn when their own ideas are considered [2].

In recent years, the curricula applied in the world have undergone a change based on the constructivist approach. It is stated that the reasons why the constructivist learning approach gains importance are that it advocates student-centered learning, increases students' motivation and thinking skills, and thus provides an effective learning environment [21].

Torrance, Amabile and Shally emphasized the importance of intrinsic motivation in creativity. Instructors have to activate the internal motivation of the students instead of extrinsic motivation. It is important in terms of creativity that activates the intrinsic motivation of individuals, is not judgmental and nonthreatening in assessment approaches, and arouses students' curiosity. Students will perceive that they are learning meaningful and valuable things when they can combine their current knowledge with new experiences by using the learning strategies they have [17].

In McDonough \& Shaw's (1998) foreign language learning research, the student's age, interests, English language proficiency level, ability, mother tongue, academic and educational level, tendency towards learning, motivation, learning reasons, preferred learning styles and personality affect the learning process. cited as important factors [3] Cooper \& McIntyre (1998) also emphasize that student's interest, knowledge, grasping power, motivation, preferred study-learning style and expectations have an important place in learning. In the 
research of Reece \& Walker (1997), it is stated that motivation is a key concept in the realization of successful learning. They also found that a less talented but highly motivated student may be more successful than a more intelligent but less motivated student. Therefore, it is understood that trainers can increase the quality of education by maximizing the motivation of the students [9]. Both parents and educators must continually develop new strategies to enable students to perform better academically [1]

\subsection{Method}

This research was carried out to measure the motivation levels of students studying in aviation departments at the higher education level. According to the results obtained in this research, the motivation levels of the students during the education were tried to be determined. In the study, the results obtained with the information obtained as a result of the survey were evaluated and suggestions were presented.

The scale used in this study was developed by Vallerand et al. in 1989, originally in French, and translated into English and used in many studies. Since the original of the scale could not be reached, the study of Ahmet Kara (2008) [12], which was adapted into Turkish, was used. The original of the scale prepared by Vallerand et al. consists of four levels. These; They are the levels of Identified Extrinsic Motivation, Amotivation, Introjected Extrinsic Motivation, and Intrinsic Motivation. Each level contains three variables in itself [9].

- Identified extrinsic motivation level: A1, B1, C1.

- Level of amotivation: A2, B2, C2.

- Introjected extrinsic motivation level: A3, B3, C3.

- Intrinsic motivation level: A4, B4, C4.

\section{Results and Discussion}

\subsection{Findings and Analysis}

Table 1: Gender Distribution of Participants

\begin{tabular}{|l|l|l|l|}
\hline & Frequency & Percent & Valid Percent \\
\hline Woman & 758 & 70,6 & 70,6 \\
\hline Man & 315 & 29,4 & 29,4 \\
\hline Total & 1073 & 100,0 & 100,0 \\
\hline
\end{tabular}

Table 2: Age Distribution of Participants

\begin{tabular}{|c|c|c|c|}
\hline & Frequency & Percent & $\begin{array}{c}\text { Valid } \\
\text { Percent }\end{array}$ \\
\hline $18-19$ & 210 & 19,6 & 19,6 \\
\hline $20-21$ & 569 & 53,0 & 53,0 \\
\hline $22-23$ & 234 & 21,8 & 21,8 \\
\hline 24 and upper & 60 & 5,6 & 5,6 \\
\hline Total & 1073 & 100 & 100 \\
\hline
\end{tabular}

While the majority of the respondents are in the 20-21 age group with $53.0 \%$, the age group of 24 and over constitutes the age group of 24 and over with $5.6 \%$.
Table 3: Class Status of Participants

\begin{tabular}{|l|l|l|l|}
\hline & Frequency & Percent & $\begin{array}{l}\text { Valid } \\
\text { Percent }\end{array}$ \\
\hline 1. Class & 247 & 23,0 & 23,0 \\
\hline 2. Class & 580 & 54,1 & 54,1 \\
\hline 3. Class & 161 & 15,0 & 15,0 \\
\hline 4. Class and upper & 85 & 7,9 & 7,9 \\
\hline Total & 1073 & 100 & 100 \\
\hline
\end{tabular}

$23.0 \%$ of the students participating in the research are 1 st grade, $54.1 \%$ are 2 nd grade, $15 \%$ are 3 rd grade, $7.9 \%$ are 4 th grade and above.

Table 4: Distribution of Participants by Department Type

\begin{tabular}{|l|l|l|l|}
\hline & Frequency & Percent & $\begin{array}{l}\text { Valid } \\
\text { Percent }\end{array}$ \\
\hline $\begin{array}{l}\text { Ground Handling } \\
\text { Services }\end{array}$ & 437 & 40,7 & 40,7 \\
\hline $\begin{array}{l}\text { A/C Maintenance } \\
\text { Services }\end{array}$ & 394 & 36,7 & 36,7 \\
\hline Cabin Services & 242 & 22,6 & 22,6 \\
\hline Total & 1073 & 100 & 100 \\
\hline
\end{tabular}

The students who participated in the survey, 437 $(40.7 \%)$ of them are in the relevant departments of ground services, $394(36.7 \%)$ of them are in the aircraft maintenance services, and $242(22.6 \%)$ of them are in the relevant departments. Students studying in aviation departments from 47 different universities participated in the research. The universities with the highest participation are Erciyes University, Istanbul Gelişim University, Istanbul Arel University, Anadolu University Nişantaşı University and Kocaeli Universityersity, Anadolu University Nişantaşı University and Kocaeli University.

Cronbach's Alpha $(\alpha)$ coefficient was used to test the reliability and consistency of each factor. Reliability analysis (Alpha Cronbach's) was made for the research data, then descriptive statistical analyzes and some non-parametric tests were applied for the statements. As a result of the analysis, the Cronbach Alpha coefficients of the variables are as in Table 5. The reliability coefficients $(\alpha)$ of all dimensions were measured above 0.70. This shows that the scales are reliable and the questions are understandable.

Table 5: Cronbach's $\alpha$ Reliability Values of Motivation Levels

\begin{tabular}{|l|l|}
\hline Types of Motivation & Cronbach's $\boldsymbol{\alpha}$ \\
\hline Introjected Extrinsic Motivation Level &, 903 \\
\hline Lack of Motivation Level &, 864 \\
\hline Intrinsic Motivation Level &, 822 \\
\hline Identified Extrinsic Motivation Level &, 940 \\
\hline General Cronbach's $\alpha$ Ratio &, 711 \\
\hline
\end{tabular}

As seen in Table 6, the eigenvalue statistics revealed in the factor analysis were greater than 1 . The KMO test is $84.7 \%$. The data set being $0.847>0.50$ indicates that it is suitable for factor 
analysis. It is seen that there is a high correlation between the variables in terms of Bartlett test $=9023,831$ and sig. $=0.000$ values. Thus, the resulting factors can be considered significant [9].

Table 6: Structure of Factors Emerging in Factor Analysis

\begin{tabular}{|l|l|l|l|}
\hline Factor & Eigenvalue & Variance & $\begin{array}{l}\text { Percentage of Total } \\
\text { Variance }\end{array}$ \\
\hline 1 & 5,366 & 44,721 & 33,809 \\
\hline 2 & 1,984 & 16,534 & 54,770 \\
\hline 3 & 1,464 & 12,200 & 66,487 \\
\hline 4 & 1,001 & 8,341 & 75,974 \\
\hline
\end{tabular}

The mean and standard deviation values from the descriptive statistical analyzes of the four levels obtained as a result of the factor analysis of the items forming the scale are shown in Table 7 . The scale is numbered as $1=$ strongly disagree, $2=$ disagree, $3=$ moderately agree/moderately disagree, 4=agree, and 5=strongly agree, according to a 5-point Liker. When examined in terms of averages; among the four motivation levels, it can be stated that the motivation levels for introjected extrinsic motivation and amotivation level are low, while intrinsic motivation and identified extrinsic motivation levels are high. It can be said that there is a linear increase from the level of introjected extrinsic motivation to the level of identified extrinsic motivation.
Table 7: Descriptive Statistics for Measuring Motivation Level

\begin{tabular}{|c|c|c|}
\hline$n=1073$ & $\mathbf{x}$ & S.d \\
\hline Introjected Extrinsic Motivation Level & 1,5290 & ,96734 \\
\hline $\begin{array}{l}\text { I go to university because my teachers and } \\
\text { my family want it. }\end{array}$ & 1,5946 & 1,09299 \\
\hline $\begin{array}{l}\text { I listen to what my teachers tell me } \\
\text { because my teachers and my family want } \\
\text { it. }\end{array}$ & 1,4744 & 1,00908 \\
\hline $\begin{array}{l}\text { I do my lesson preparations because my } \\
\text { teachers and my family want it. }\end{array}$ & 1,5182 & 1,06763 \\
\hline Lack of Motivation Level & 1,8263 & 1,13313 \\
\hline $\begin{array}{l}\text { I'm going to university, but I don't know } \\
\text { how it will benefit me. }\end{array}$ & 1,8751 & 1,31554 \\
\hline $\begin{array}{l}\text { I do my homework and responsibilities, but } \\
\text { I don't know what benefit it will bring. }\end{array}$ & 1,8695 & 1,30074 \\
\hline $\begin{array}{l}\text { I listen to what my teachers tell in class, } \\
\text { but I don't know how it will benefit me. }\end{array}$ & 1,7344 & 1,21377 \\
\hline Intrinsic Motivation Level: & 3,7226 & 1,16203 \\
\hline $\begin{array}{l}\text { I am happy when I do my project } \\
\text { assignments given at the university. }\end{array}$ & 3,5694 & 1,43291 \\
\hline $\begin{array}{l}\text { I am happy when I listen to what my } \\
\text { teachers say in class. }\end{array}$ & 3,8406 & 1,26142 \\
\hline $\begin{array}{l}\text { I go to university because when I go to } \\
\text { school, I am happy. }\end{array}$ & 3,7577 & 1,36076 \\
\hline Level of Identified Extrinsic Motivation: & 4,5020 & ,97130 \\
\hline $\begin{array}{l}\text { I listen to what my teachers tell in class for } \\
\text { my own good. }\end{array}$ & 4,4604 & 1,04942 \\
\hline I go to school for my own sake. & 4,5200 & 1,00920 \\
\hline I do my work for my own good. & 4,5256 & 1,02376 \\
\hline
\end{tabular}

When examined in general, it is seen that there is a relationship between all levels within motivation levels. It is seen that the highest relationship is between the intrinsic motivation level and the identified extrinsic motivation level $(\mathrm{r}=0.515 ; 0.00<0.01)$. There is a negative relationship between lack of motivation level and intrinsic motivation level ( $\mathrm{r}=-0.451$; $0.00<0.01)$ and between identified extrinsic motivation levels $(\mathrm{r}=-0.351 ; 0.00<0.01)$.

First of all, the normality of the data was tested with the Kolmogorov Smirnov test, and it was found that it did not have a normal distribution as the significance value was less than 0.5 . For this reason, Mann-Whitney $U$ and Kruskal Wallis tests, which are non-parametric tests, were used. According to the Mann-Whitney $U$ test result table seen in Table 9, there is a significant difference between the gender of the participants and the four motivation levels. [ $\mathrm{U}=100382,000, \mathrm{p}=0,000<0.05]$. 
Table 8: The Relationship between Motivations Levels

\begin{tabular}{|c|c|c|c|c|c|}
\hline & & 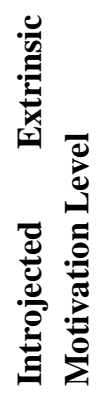 & 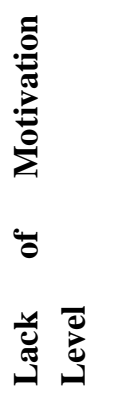 & 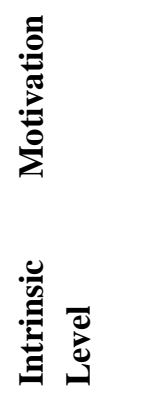 & 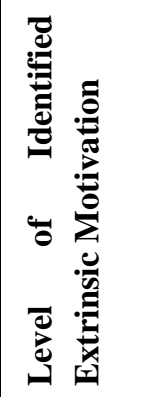 \\
\hline Introjected Extrinsic Motivation Level & r p value & 1 & $\begin{array}{l}, 456(* *) \\
, 000\end{array}$ & $\begin{array}{l}-, 269(* *) \\
, 000\end{array}$ & $\begin{array}{l}-, 337(* *) \\
, 000\end{array}$ \\
\hline Lack of Motivation Level & $\mathrm{rp}$ value & & 1 & $\begin{array}{l}-, 451(* *) \\
, 000\end{array}$ & $\begin{array}{l}-, 351(* *) \\
, 000\end{array}$ \\
\hline Intrinsic Motivation Level & $\mathrm{rp}$ value & & & 1 & $\begin{array}{l}, 515(* *) \\
, 000\end{array}$ \\
\hline Level of Identified Extrinsic Motivation & r p value & & & & 1 \\
\hline
\end{tabular}

Table 9: Variation of Motivation Level by Gender

\begin{tabular}{|c|c|c|c|c|c|c|}
\hline & Gender & $\mathbf{n}$ & Average Rank & Total Row & $\mathbf{U}$ & $\mathbf{p}$ \\
\hline \multirow{2}{*}{$\begin{array}{c}\text { Introjected Extrinsic } \\
\text { Motivation Level }\end{array}$} & Man & 758 & 562,07 & 426049,00 & \multirow{2}{*}{100382,000} & \multirow{2}{*}{,000 } \\
\hline & Woman & 315 & 476,67 & 150152,00 & & \\
\hline \multirow{2}{*}{$\begin{array}{c}\text { Lack of Motivation } \\
\text { Level }\end{array}$} & Man & 758 & 562,59 & 426440,00 & \multirow{2}{*}{99991,000} & \multirow{2}{*}{,000 } \\
\hline & Woman & 315 & 475,43 & 149761,00 & & \\
\hline \multirow{2}{*}{$\begin{array}{c}\text { Intrinsic Motivation } \\
\text { Level }\end{array}$} & Man & 758 & 516,07 & 391180,00 & \multirow{2}{*}{103519,000} & \multirow{2}{*}{, 001} \\
\hline & Woman & 315 & 587,37 & 185021,00 & & \\
\hline \multirow{2}{*}{$\begin{array}{l}\text { Level of Identified } \\
\text { Extrinsic Motivation }\end{array}$} & Man & 758 & 520,80 & 394767,00 & \multirow{2}{*}{107106,000} & \multirow{2}{*}{,002 } \\
\hline & Woman & 315 & 575,98 & 181434,00 & & \\
\hline
\end{tabular}

Table 10. As can be seen, there is a statistically significant difference between the age variable and the lack of motivation level of the participants $[\chi 2=8,991, \mathrm{p}=0.029<0.05]$. Man-Whitney $U$ test was applied between each pair and it was seen that the significant difference was between the 18-19 age group, the 20-21 age group, the 18-19 age group and the 22-23 age group. A significant difference was also observed between the level of identified extrinsic motivation and age $[\chi 2=9,468, p=0.024<0.05]$. As a result of the applied ManWhitney U test, it was observed that there was a significant difference between the 20-21 age group and the 22-23 age group.
Kruskal Wallis test was applied to make sense of the relationship between the class variable and motivation levels in the Table 11. As a result of this test, statistically significant differences were found between all four motivation levels and class variables. The binary class variables for each motivation type were evaluated with the Man-Whitney $U$ test and the pairs that made a significant difference were determined. 
European Journal of Science and Technology

Table 10: Variation of Motivation Level by Age

\begin{tabular}{|c|c|c|c|c|c|c|c|}
\hline & Age & $\mathbf{n}$ & $\begin{array}{l}\text { Average } \\
\text { Rank }\end{array}$ & sd & $\chi^{2}$ & $\mathbf{p}$ & Difference \\
\hline \multirow{4}{*}{$\begin{array}{l}\text { Introjected Extrinsic } \\
\text { Motivation Level }\end{array}$} & $18-19$ & 210 & 542,40 & \multirow{4}{*}{3} & \multirow{4}{*}{2,300} & \multirow{4}{*}{, 513} & \multirow{4}{*}{ - } \\
\hline & $20-21$ & 569 & 530,80 & & & & \\
\hline & $22-23$ & 234 & 555,33 & & & & \\
\hline & 24 and upper & 60 & 505,40 & & & & \\
\hline \multirow{4}{*}{$\begin{array}{l}\text { Lack of Motivation } \\
\text { Level }\end{array}$} & 18-19 & 210 & 492,05 & \multirow{4}{*}{3} & \multirow{4}{*}{8,991} & \multirow{4}{*}{,029 } & \multirow{4}{*}{$\begin{array}{l}1-2 \\
P=, 049 \\
1-3 \\
P=, 003\end{array}$} \\
\hline & $20-21$ & 569 & 537,80 & & & & \\
\hline & $22-23$ & 234 & 575,22 & & & & \\
\hline & 24 and upper & 60 & 537,68 & & & & \\
\hline \multirow{4}{*}{$\begin{array}{l}\text { Intrinsic Motivation } \\
\text { Level }\end{array}$} & $18-19$ & 210 & 537,04 & \multirow{4}{*}{3} & \multirow{4}{*}{2,367} & \multirow{4}{*}{, 500} & \multirow{4}{*}{ - } \\
\hline & $20-21$ & 569 & 546,31 & & & & \\
\hline & $22-23$ & 234 & 510,76 & & & & \\
\hline & 24 and upper & 60 & 550,90 & & & & \\
\hline \multirow{4}{*}{$\begin{array}{l}\text { Level of Identified } \\
\text { Extrinsic Motivation }\end{array}$} & $18-19$ & 210 & 529,08 & \multirow{4}{*}{3} & \multirow{4}{*}{9,468} & \multirow{4}{*}{, 024} & \multirow{4}{*}{$\begin{array}{l}2-3 \\
P=, 002\end{array}$} \\
\hline & $20-21$ & 569 & 556,55 & & & & \\
\hline & $22-23$ & 234 & 494,99 & & & & \\
\hline & 24 and upper & 60 & 543,12 & & & & \\
\hline
\end{tabular}

Kruskal Wallis test was applied to make sense of the relationship between the class variable and motivation levels in the Table 11. As a result of this test, statistically significant differences were found between all four motivation levels and

class variables. The binary class variables for each motivation type were evaluated with the Man-Whitney $U$ test and the pairs that made a significant difference were determined.

Table 11: Variation of Motivation Level by Educational Status

\begin{tabular}{|c|c|c|c|c|c|c|c|}
\hline & Class & $\mathrm{n}$ & $\begin{array}{l}\text { Average } \\
\text { Rank }\end{array}$ & sd & $\chi^{2}$ & $\mathrm{p}$ & Difference \\
\hline \multirow{4}{*}{$\begin{array}{l}\text { Introjected Extrinsic } \\
\text { Motivation Level }\end{array}$} & 1. Class & 247 & 517,82 & \multirow{4}{*}{3} & \multirow{4}{*}{10,861} & \multirow{4}{*}{013} & \multirow{4}{*}{$\begin{array}{l}1-3 \\
P=, 039 \\
1-4 \\
P=, 012 \\
2-3 \\
P=, 036 \\
2-4 \\
P=, 011\end{array}$} \\
\hline & 2. Class & 580 & 524,85 & & & & \\
\hline & 3. Class & 161 & 575,02 & & & & \\
\hline & 4. Class & 85 & 603,63 & & & & \\
\hline \multirow{4}{*}{ Lack of Motivation Level } & 1. Class & 247 & 486,54 & \multirow{4}{*}{3} & \multirow{4}{*}{17,839} & \multirow{4}{*}{, 000} & \multirow{4}{*}{$\begin{array}{l}1-2 \\
P=, 035 \\
1-3 \\
P=, 000 \\
1-4 \\
P=, 002 \\
2-3 \\
P=, 019 \\
2-4 \\
P=, 049\end{array}$} \\
\hline & 2. Class & 580 & 533,10 & & & & \\
\hline & 3. Class & 161 & 594,74 & & & & \\
\hline & 4. Class & 85 & 600,87 & & & & \\
\hline \multirow{4}{*}{ Motivation } & 1. Class & 247 & 625,64 & \multirow{4}{*}{3} & \multirow{4}{*}{53,994} & \multirow{4}{*}{, 000} & \multirow{4}{*}{$\begin{array}{l}1-2 \\
\mathrm{P}=, 001 \\
1-3 \\
\mathrm{P}=, 000 \\
1-4 \\
\mathrm{P}=, 000 \\
2-3 \\
\mathrm{P}=, 000 \\
2-4 \\
\mathrm{P}=, 002\end{array}$} \\
\hline & 2. Class & 580 & 546,53 & & & & \\
\hline & 3. Class & 161 & 419,71 & & & & \\
\hline & 4. Class & 85 & 436,55 & & & & \\
\hline
\end{tabular}




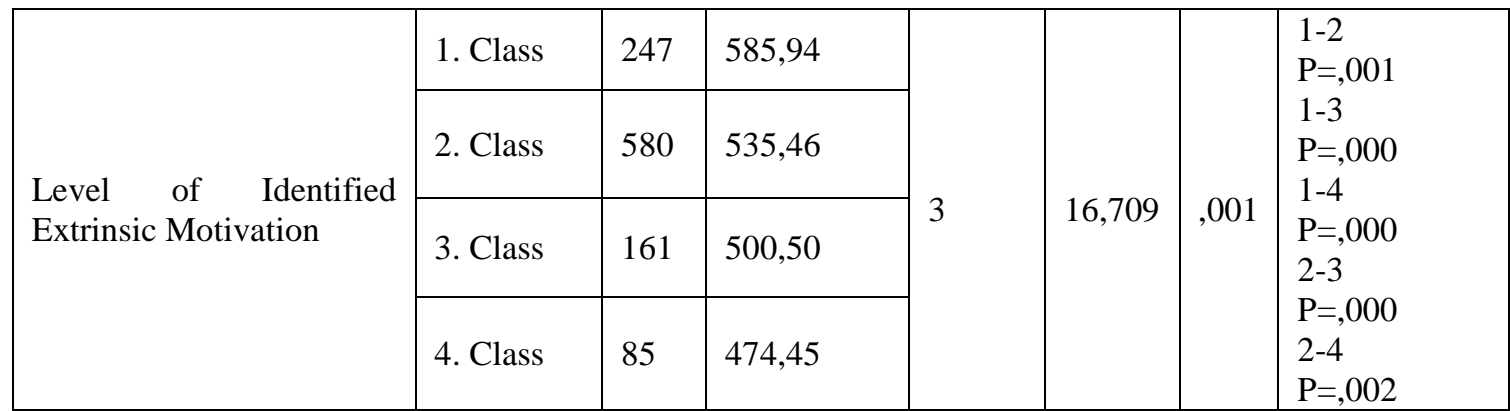

In Table 12, the Kruskal Wallis test was applied to make sense of the relationship between department type and motivation levels. As a result of this test, statistically significant differences were found between all four motivation levels and age variables. For each motivation type, the binary part type variables were evaluated with the Man-Whitney $U$ test and the pairs that created the significant difference were determined. Significant differences were found in cabin services and the other two section type variables in all four motivation types.

Table 12: Variation of Motivation Level by Department Type

\begin{tabular}{|c|c|c|c|c|c|c|c|}
\hline & Type of Department & $\mathbf{n}$ & $\begin{array}{c}\text { Average } \\
\text { Rank }\end{array}$ & sd & $\chi^{2}$ & $\mathbf{p}$ & Difference \\
\hline \multirow{3}{*}{$\begin{array}{c}\text { Introjected } \\
\text { Extrinsic } \\
\text { Motivation Level }\end{array}$} & Ground Handling & 437 & 554,63 & \multirow{3}{*}{2} & \multirow{3}{*}{24,538} & \multirow{3}{*}{,000 } & \multirow{3}{*}{$\begin{array}{c}1-3 \\
\mathrm{P}=, 000 \\
2-3 \\
\mathrm{P}=, 000\end{array}$} \\
\hline & $\begin{array}{l}\text { A/C Maintenance } \\
\text { Services }\end{array}$ & 394 & 563,55 & & & & \\
\hline & Cabin Services & 242 & 461,93 & & & & \\
\hline \multirow{3}{*}{$\begin{array}{l}\text { Lack of Motivation } \\
\text { Level }\end{array}$} & Ground Handling & 437 & 553,70 & \multirow{3}{*}{2} & \multirow{3}{*}{16,610} & \multirow{3}{*}{, 000} & $1-3$ \\
\hline & $\begin{array}{l}\text { A/C Maintenance } \\
\text { Services }\end{array}$ & 394 & 559,71 & & & & $\begin{array}{l}P=, 000 \\
2-3\end{array}$ \\
\hline & Cabin Services & 242 & 469,85 & & & & $\mathrm{P}=, 000$ \\
\hline \multirow{3}{*}{$\begin{array}{l}\text { Intrinsic Motivation } \\
\text { Level }\end{array}$} & Ground Handling & 437 & 526,24 & \multirow{3}{*}{2} & \multirow{3}{*}{19,248} & \multirow{3}{*}{, 000} & $1-3$ \\
\hline & $\begin{array}{l}\text { A/C Maintenance } \\
\text { Services }\end{array}$ & 394 & 503,63 & & & & $\begin{array}{l}\mathrm{P}=, 001 \\
2-3\end{array}$ \\
\hline & Cabin Services & 242 & 610,76 & & & & $\mathrm{P}=, 000$ \\
\hline \multirow{3}{*}{$\begin{array}{l}\text { Level of Identified } \\
\text { Extrinsic } \\
\text { Motivation }\end{array}$} & Ground Handling & 437 & 527,11 & \multirow{3}{*}{2} & \multirow{3}{*}{17,473} & \multirow{3}{*}{, 000} & $1-3$ \\
\hline & $\begin{array}{l}\text { A/C Maintenance } \\
\text { Services }\end{array}$ & 394 & 510,91 & & & & $\begin{array}{l}\mathrm{P}=, 001 \\
2-3\end{array}$ \\
\hline & Cabin Services & 242 & 597,34 & & & & $\mathrm{P}=, 000$ \\
\hline
\end{tabular}

\section{Conclusion}

The importance of the education system in the development and progress of societies and the development of individuals is very high modern industry. The education system needs to be designed and updated to meet current needs. The most important element that will bring the education system to a quality level is technology. Therefore, it is not possible to consider the education system separately from technological developments. With the advancement of technology, there are also changes in the field of education. Recently, technology-assisted trainings such as computer-assisted education and distance education have begun to be given. The importance of motivation in achieving the goals and objectives of the trainings given in educational institutions is becoming more and more felt day by day.

Considering the motivation levels of the students; it can be stated that motivation levels related to introjected extrinsic motivation and lack of motivation levels are low, whereas intrinsic motivation and identified extrinsic motivation levels are high. Therefore, it can be said that students integrate the high e-ISSN: 2148-2683 motivation they have experienced in their education with the instructors that directly affect them when viewed from the outside. The fact that students have positive feelings towards the instructors and the educational institution they are registered with may also cause their identified external motivation to be high. Because identified extrinsic motivation requires a goal. The criterion here is the goal of being a successful student. Thus, the student draws attention to how important the influence of the instructors is in the high level of both internal and external motivation. It is thought that the high level of motivation in this area will lead to an increase in the emotional commitment of the student at the same time, and the probability of being an unsuccessful student will decrease.

There are some benefits of a high level of the motivation in aviation education. First of all high level of motivation in education enhances the efficiency of the studens. It enables more efficient use of resources. It contributes to the continuous development of students. It reduces students' dissatisfaction with education and enables them to continue in education. It ensures 
the formation of a positive culture in the education environment. It improves students' attitudes and behaviors.

In general, it is seen that there is a relationship between students' motivation levels in education. It is seen that the highest relationship is between the intrinsic motivation level and the identified extrinsic motivation level. At the same time, there is a negative relationship between the level of lack of motivation and the level of intrinsic motivation, and between the levels of identified extrinsic motivation.

Considering that introjected extrinsic motivation-internal pressures such as guilt or feelings of self-worth as the cause of behaviors-is considered, it is remarkable that this level of motivation ranks first in the study. As a matter of fact, under this result; there may be a feeling of guilt or hesitation, especially from the negative reactions that the student will receive from his family and social environment, in continuing his education or being motivated to the educational institution/instructor. Considering that this behavior is important for the goal that the individual has set for himself, it may be that the students' low motivation may be caused by the absence of something they have set as a goal.

There is a statistically significant difference between the age variable and the lack of motivation level of the participants. It was observed that the significant difference between each pair was between the 18-19 age group, the 20-21 age group, and the 18-19 age group and the 22-23 age group. A significant difference was also observed between the level of identified extrinsic motivation and age. As another result, it was observed that there was a significant difference between the 20-21 age group and the 22-23 age group. As a result of the tests applied, statistically significant differences were found between all four motivation levels and age variables. For each motivation type, the binary part type variables were evaluated and the pairs that created the significant difference were determined. Significant differences were found in all four motivation types of students in departments related to cabin services, ground services and maintenance services.

As a result of the tests applied to make sense of the relationship between the class variable and motivation levels, statistically significant differences were found between all four motivation levels and class variables. As a result, when the motivation levels of the students in education are examined in terms of four motivation levels, it can be said that the levels of identified extrinsic motivation and intrinsic motivation are high, the lack of motivation levels and introjected extrinsic motivation is low, and the level of motivation varies according to gender, age, department type and educational status.

\section{References}

[1] Akbaba, S. (2006). Eğitimde Moivasyon. Kazım Karabekir Eğitim Fakültesi Dergisi, 347-348.

[2] Alşan, E. U. (2009). Kimya Öğretmen Adaylarının Akademik Başarılarına Öğrenme Stili Tercihleri Öz Kontrollü Öğrenme ve Motivasyon Faktörlerinin Etkisi. Hacettepe Üniversitesi Doktora Tezi.

[3] Anjomshoa, L., \& Sadighi, F. (2015). The Importance of Motivation in Second Language Acquisition. International Journal on Studies in English Language and Literature (IJSELL), 3(2), 126-137.
[4]Bayraktar, H. V. (2015). Sınıf Yönetiminde Öğrenci Motivasyonu ve Motivasyonu Etkileyen Etmenler. Turkish Studies, 1079-1100.

[5]Çakır, E. (2006). Anadolu Öğretmen Lisesinde Okuyan Öğrencilerin Depresyon ve Motivasyon Düzeyleri. Sakarya Üniversitesi Yüksek Lisans Tezi.

[6]Çoban, G. S. (2021). Maslow’un İhtiyaçlar Hiyerarşisi Kendini Gerçekleştirme Basamağında Gizil Yetenekler. European Journal of Educational \& Social Sciences, 6(1), 111-118.

[8]Demir, H., \& Okan, T. (2009). Motivasyon Üzerinde Ulusal Kültür Etkisi. Gazi Üniversitesi İktisadi ve İdari Bilimler Fakültesi Dergisi, 11(1), 121-142.

[9]Gürdoğan, A. (2012). Öğrencilerin Eğitimde Motivasyon Düzeyleri Muğla Sitkı Koçman Üniversitesi Ortaca Meslek Yüksekokulu Örneği. Sosyal Bilimler Dergisi(22), 149-165.

[10] İşigüzel, B. (2013). Turizm İşletmeciliği ve Otelcilik Programlarındaki Mesleki Almanca Dersleri Üzerine Bir Araştırma. E-Journal of New World Sciences Academy, 363371. Retrieved from http://www.turkishstudies.net/DergiTamDetay.aspx?ID=557 2

[11]Jesus, S. N., \& Lens, W. (2005). An Integrated Model for the Study of Teacher Motivation. Applied Psychology: An International Review, 119-134.

[12]Kara, A. (2008). İlköğretim Birinci Kademede Eğitimde Motivasyon Ölçeğinin Türkçeye Uyarlanması. Ege Eğitim Dergisi, C (9), Say1 (2), 59-78.

[13]Keenan, K. (1996). Yöneticinin Kilavuzu Motivasyon. Remzi Kitabevi.

[14]Keskin, B. (2008). Çalışanların Performanslarını Artırmada Bir Araç Olarak Motivasyon ve Motivasyon Teknikleri. Yayınlanmamış Yüksek Lisans Tezi.

[15]Kumkale, T. T. (1998). Türklerde Motivasyon: Türk İnsan MÜhendisliği. Paperback.

[16]Robbins, S. P., \& Judge, T. A. (2012). Örgütsel Davranış. (İ. Erdem, Trans.) Nobel.

[17]Tuan, H.-L., Chin, C.-C., \& Shieh, S.-H. (2005). The development of a questionnaire to measurestudents' motivation towards science learning. International Journal of Science Education, 27(6), 639-654.

[18]TUIK. (2020). İstatistiklerle Gençlik, 2020. Ankara: Türkiye İstatistik Kurumu. Retrieved 2021, from https://data.tuik.gov.tr/Bulten/Index?p=IstatistiklerleGenclik-2020-37242

[19]Tutar, H. (2013). İşletme \& Yönetim Terimleri Ansiklopedik Sözlük. Detay.

[20]Ünal, H. (2014). Çalışma Hayatında Örgütsel Bağlılık ve Motivasyon (Denizli İl Merkezinde Bir Kamuya Bağlı Devlet Hastanesi Hemşireleri Örneği). Yayınlanmamış Yüksek Lisans Tezi.

[21]Yelken, T. Y., Üredi, L., Tanrıseven, I., \& Kılıç, F. (2010). İlköğretim Müfettişlerinin Yapılandırmacı Program ile Öğretmenlerin Yapılandırmacı Öğrenme Ortamı Oluşturma Düzeylerine İlişkin Görüşleri. Ç.Ü. Sosyal Bilimler Enstitüsü Dergisi, 19(2), 31-46. 